\title{
PPAR $\gamma$ and C/EBP factors orchestrate adipocyte biology via adjacent binding on a genome-wide scale
}

\author{
Martina I. Lefterova, ${ }^{1}$ Yong Zhang, ${ }^{2}$ David J. Steger, ${ }^{1}$ Michael Schupp, ${ }^{1}$ Jonathan Schug, ${ }^{3}$ \\ Ana Cristancho, ${ }^{1}$ Dan Feng, ${ }^{1}$ David Zhuo, ${ }^{1}$ Christian J. Stoeckert Jr., ${ }^{3}$ X. Shirley Liu, ${ }^{2}$ \\ and Mitchell A. Lazar ${ }^{1,4}$ \\ ${ }^{1}$ Institute for Diabetes, Obesity, and Metabolism, and Division of Endocrinology, Diabetes, and Metabolism, University of \\ Pennsylvania School of Medicine, Philadelphia, Pennsylvania 19104, USA; ${ }^{2}$ Department of Biostatistics and Computational \\ Biology, Dana-Farber Cancer Institute, Harvard School of Public Health Boston, Massachusetts 02115, USA; ${ }^{3}$ Department of \\ Genetics, School of Medicine, Center for Bioinformatics, University of Pennsylvania, Philadelphia, Pennsylvania 19104, USA
}

Peroxisome proliferator-activated receptor $\gamma(\operatorname{PPAR} \gamma)$, a nuclear receptor and the target of anti-diabetic thiazolinedione drugs, is known as the master regulator of adipocyte biology. Although it regulates hundreds of adipocyte genes, PPAR $\gamma$ binding to endogenous genes has rarely been demonstrated. Here, utilizing chromatin immunoprecipitation (ChIP) coupled with whole genome tiling arrays, we identified 5299 genomic regions of PPAR $\gamma$ binding in mouse 3T3-L1 adipocytes. The consensus PPAR $\gamma / \mathrm{RXR} \alpha$ "DR-1"-binding motif was found at most of the sites, and ChIP for RXR $\alpha$ showed colocalization at nearly all locations tested. Bioinformatics analysis also revealed CCAAT/enhancer-binding protein (C/EBP)-binding motifs in the vicinity of most PPAR $\gamma$-binding sites, and genome-wide analysis of C/EBP $\alpha$ binding demonstrated that it localized to 3350 of the locations bound by PPAR $\gamma$. Importantly, most genes induced in adipogenesis were bound by both $\operatorname{PPAR} \gamma$ and C/EBP $\alpha$, while very few were PPAR $\gamma$-specific. C/EBP $\beta$ also plays a role at many of these genes, such that both C/EBP $\alpha$ and $\beta$ are required along with PPAR $\gamma$ for robust adipocyte-specific gene expression. Thus, PPAR $\gamma$ and C/EBP factors cooperatively orchestrate adipocyte biology by adjacent binding on an unanticipated scale.

[Keywords: PPAR $\gamma$; C/EBP; adipocyte; genome wide; ChIP-chip]

Supplemental material is available at http://www.genesdev.org.

Received June 24, 2008; revised version accepted August 29, 2008.

Peroxisome proliferator-activated receptor $\gamma(\operatorname{PPAR} \gamma)$, a member of the nuclear receptor superfamily of ligandactivated transcription factors, is the cellular target of anti-diabetic thiazolidinedione drugs (TZDs). PPAR $\gamma$ is both necessary (Rosen et al. 2002) and sufficient (Tontonoz et al. 1994c) for the differentiation of mouse fibroblasts into adipocytes, where PPAR $\gamma$ is expressed at its highest levels (Chawla et al. 1994; Tontonoz et al. 1994b). The adipogenic activity of PPAR $\gamma$ requires a functional DNA-binding domain (Tontonoz et al. 1994c), suggesting that this critical function involves binding directly to target genes. PPAR $\gamma$ is also important for major functions of mature adipocytes, including lipid metabolism, adipokine secretion, and insulin sensitivity (Rangwala and Lazar 2004). A number of animal models and naturally occurring human mutations have demon-

${ }^{4}$ Corresponding author.

E-MAIL lazar@mail.med.upenn.edu; FAX (215) 898-5408.

Article is online at http://www.genesdev.org/cgi/doi/10.1101/gad.1709008. strated that PPAR $\gamma$ plays critical roles in adipocyte development and function in vivo as well (Gray et al. 2005).

PPAR $\gamma$ regulates adipocyte biology together with members of the CCAAT/enhancer-binding protein $(\mathrm{C} /$ EBP) family. C/EBP $\beta$ and $\mathrm{C} / \mathrm{EBP} \delta$ are expressed early during adipogenesis (Cao et al. 1991; Yeh et al. 1995), and are involved in the induction of PPAR $\gamma(\mathrm{Wu}$ et al. 1996; Hamm et al. 2001). C/EBP $\alpha$ is induced at later stages and is active in mature adipocytes (Darlington et al. 1998). Ectopic expression of C/EBP $\alpha$ (Freytag et al. 1994; Tontonoz et al. 1994c) or C/EBPß (Wu et al. 1995; Yeh et al. 1995) can induce NIH-3T3 fibroblasts to differentiate, although this requires PPAR $\gamma(\mathrm{Wu}$ et al. 1996). Coexpression of $\mathrm{C} / \mathrm{EBP} \alpha$ and PPAR $\gamma$ in NIH-3T3 cells has synergistic effects on adipogenic conversion and essentially obviates the need for hormonal stimulation (Tontonoz et al. 1994c). This suggests that the cooperation of PPAR $\gamma$ with C/EBP family members is necessary for optimal differentiation, although the precise mechanism of this cooperation remains unclear.

Based on in vitro studies and target genes identified in 
the literature, PPAR $\gamma$ binds consensus DNA elements as a heterodimer with $\mathrm{RXR} \alpha$ in a head-to-tail orientation (Gearing et al. 1993; IJpenberg et al. 1997). Known PPAR $\gamma$-binding sites contain the so-called "DR1" site; i.e., a direct repeat of the AGGTCA element conserved to various degrees and separated by a single nucleotide (Schoonjans et al. 1996). These conclusions are based on analysis of only $\sim 30$ genes identified as PPAR $\gamma$ targets through reporter gene and gel shift assays and chromatin immunoprecipitation (ChIP) (Tontonoz et al. 1994a; IJpenberg et al. 1997; Robinson et al. 1998; Teboul et al. 2001; Chui et al. 2005; Guan et al. 2005; Yajima et al. 2007; Nakachi et al. 2008). In contrast, expression profiling studies during adipocyte differentiation and following PPAR $\gamma$ ligand treatment suggest that hundreds of genes may be regulated by PPAR $\gamma$ (Perera et al. 2006; Sears et al. 2007; Nakachi et al. 2008). Thus, the full range of PPAR $\gamma$-binding sites in adipocytes, or cistrome (Lupien et al. 2008), remains largely unknown. It is also unclear where PPAR $\gamma$-binding sites are located relative to transcription start sites (TSS), and whether other transcription factors colocalize with PPAR $\gamma$ to enhance or antagonize its activity.

Here, we used ChIP followed by DNA hybridization to whole-genome tiling arrays (ChIP-chip) to determine the PPAR $\gamma$ cistrome in mouse 3T3-L1 adipocytes. We identified 5299 binding regions, with a false discovery rate of $1 \%$, most of which are novel and located in distal intergenic regions and introns rather than proximal promoters. The vast majority of regions bound by PPAR $\gamma$ are also bound by $\mathrm{RXR} \alpha$ and contain the consensus DR1 element. Surprisingly, consensus C/EBP-binding motifs were identified within $>90 \%$ of $\operatorname{PPAR} \gamma$ recruitment sites, and direct ChIP-chip analysis confirmed colocalization of $\mathrm{C} / \mathrm{EBP} \alpha$ at the majority of PPAR $\gamma$-binding regions. Examination of PPAR $\gamma$ and $\mathrm{C} / \mathrm{EBP} \alpha$ binding near genes up-regulated in differentiation revealed that $60 \%$ of the genes are bound by both factors, whereas $3 \%$ of the genes are bound by PPAR $\gamma$ only and $25 \%$ by C/EBP $\alpha$ alone. Furthermore, depletion of PPAR $\gamma$ and C/EBP factors in mature adipocytes led to synergistic decreases in expression of common target genes. This suggests that the mechanism by which PPAR $\gamma$ and C/EBP factors cooperatively orchestrate adipocyte differentiation involves binding to a largely overlapping set of gene targets.

\section{Results}

Identification and validation of novel PPAR $\gamma$-binding sites

Genome wide ChIP-chip for PPAR $\gamma$ was employed on 3T3-L1 adipocytes harvested at day 10 post-hormonal induction of adipogenesis using standard techniques. The antibody against PPAR $\gamma$ was demonstrated to be specific (Supplemental Fig. S1A), and to enrich for known PPAR $y$ target sites on the Fabp4/aP and Cd36 genes relative to negative control sites (Supplemental Fig. S1B). The ChIP DNA was amplified by 25 cycles of ligation-mediated PCR (Lee et al. 2006), and analysis of the amplified DNA at the Fabp4/aP and Cd36 sites indicated that no major bias was introduced by this procedure (Supplemental Fig. S1C). Three biological replicates for PPAR $\gamma$ and control IgG were hybridized to the wholegenome Mouse Tiling 2.0R Array Set (Affymetrix), and the data were analyzed using the model-based analysis of tiling arrays (MAT) (Carroll et al. 2006; Johnson et al. 2006), using the cutoffs of false discovery rate $\leq 1 \%$ and enrichment of PPAR $\gamma$ signal over IgG equal to or greather than twofold. This analysis identified 5299 unique regions of 1000 -base-pair (bp) length, including known sites at Fabp4/aP2, Cd36, Lipe/Hsl, Olr1, and Me1 (Supplemental Table 1).

To validate the results of the PPAR $\gamma$ ChIP-chip, PPAR $\gamma$ enrichment was assayed by ChIP-quantitative PCR (QPCR) at 95 novel locations; 92 of these were true positives, suggesting an actual false discovery rate of $\sim 3 \%$. Fifteen of the sites were also tested by ChIP-QPCR with two different PPAR $\gamma$ antibodies, which led to similar results as the original antibody used for the arrays (Supplemental Fig. S2). As additional validation, one of these antibodies was used for ChIP-chip on custom "PPAR $\gamma$-binding site" arrays that densely tile 1431 randomly selected PPAR $\gamma$-binding regions. Of those, 1370 $(95.7 \%)$ were enriched using the alternative antibody on this novel chip platform. Taken together, these data indicate that the vast majority of the newly discovered sites are indeed bound by endogenous PPAR $\gamma$ in adipocytes.

To test the effect of ligand, PPAR $\gamma$ ChIP-chip was performed on adipocytes treated with $1 \mu \mathrm{M}$ rosiglitazone for $24 \mathrm{~h}$, using an array that interrogates mouse chromosomes 6,8 , and 16 . Using normalization to IgG and a statistical cutoff of FDR $\leq 5 \%, 185$ binding regions were found, of which only seven had not been previously identified in the genome-wide PPAR $\gamma$ ChIP-chip performed in the absence of exogenous ligand (data not shown). These seven sites were located either in gene-poor regions or near nonadipocyte genes and had low enrichment values, suggesting that they may be false positives. Indeed, ChIP-QPCR analysis of rosiglitazone-treated adipocytes at the seven sites did not reveal substantial PPAR $\gamma$ enrichment over IgG (data not shown). These findings indicate that there is little or no additional binding of PPAR $\gamma$ upon exogenous ligand stimulation, which is consistent with reported in vitro data indicating that DNA binding by PPAR $\gamma$ is ligand-independent ( $\mathrm{Li}$ and Glass 2004; Lehrke and Lazar 2005).

\section{Location of novel PPAR $\boldsymbol{\gamma}$-binding regions relative to known genes}

The cis-regulatory element annotation system, CEAS (Ji et al. 2006), was next employed to map the novel PPAR $\gamma$ binding regions relative to annotated genes in the mouse genome. This analysis revealed that $<7 \%$ of the genomic locations of PPAR $\gamma$ binding in adipocytes are at proximal promoters, defined here as $<1 \mathrm{~kb}$ from the TSS (Fig. 1A). Expanding the definition of proximal promoter to $10 \mathrm{~kb}$ 
A

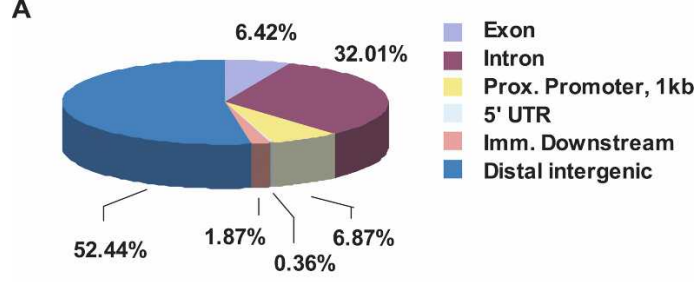

B

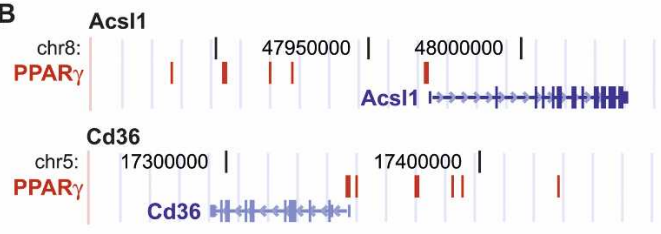

C

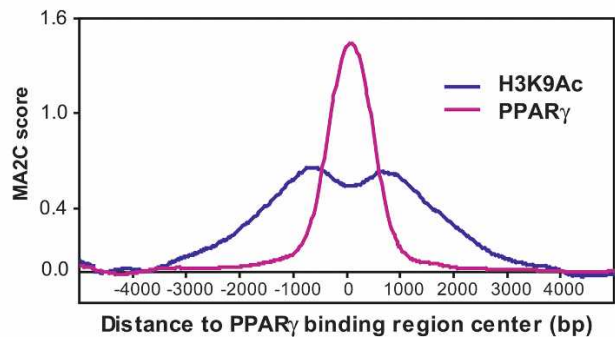

Figure 1. Location analysis of PPAR $\gamma$-binding sites. $(A)$ PPAR $\gamma$-binding regions were mapped relative to their nearest RefSeq genes using CEAS (Ji et al. 2006). Proximal (prox.) promoter was defined as $\leq 1 \mathrm{~kb}$ upstream from the TSS. Immediate (imm.) downstream was defined as $\leq 1 \mathrm{~kb}$ downstream from the 3 ' end of the gene. Distal intergenic refers to all locations outside the boundaries of a gene and the $1 \mathrm{~kb}$ flanking the gene on either end. (UTR) Untranslated region. (B) PPAR $\gamma$-binding regions are frequently clustered around target genes. Two PPAR $\gamma$ target genes, Cd36 and Acsl1, are shown in their native chromosomal locations according to the February 2006 Mouse Genome Assembly (mm8) in the UCSC Genome Browser (http:// genome.ucsc.edu). Red blocks represent regions of enriched PPAR $\gamma$-binding signal. Vertical lines within the genes represent exons, horizontal lines represent introns, and arrowheads represent the direction of transcription. $(C)$ Enrichment of acetylation at Lys 9 of histone 3 (H3K9Ac) in the regions of PPAR $\gamma$ binding. Shown are the average ChIP-chip profiles for PPAR $\gamma$ and H3K9Ac across 740 PPAR $\gamma$-binding regions located $>10 \mathrm{~kb}$ from a TSS. MA2C score refers to the enrichment at each location along the $10 \mathrm{~kb}$ distance that was tiled on the custom array for each region.

from the TSS increased the percentage of binding regions falling in this category only to $12.6 \%$ (670 out of 5299 sites). By contrast, $>50 \%$ of the sites fall within distal intergenic regions (defined as $>1 \mathrm{~kb} 5^{\prime}$ from the TSS, and $>1 \mathrm{~kb} \mathrm{3}$ ' from the end of the gene), and many other sites $(32 \%)$ are located in introns (Fig. 1A). Importantly, many regions of PPAR $\gamma$ binding are clustered such that a single gene may have multiple sites in its proximity, as can be seen for the Acsl1 (acyl-CoA synthetase 1) and Cd36 genes in Figure 1B.

\section{Functionality of novel PPAR $\boldsymbol{\gamma}$-binding sites}

To assess the functionality of novel PPAR $\gamma$-binding sites uncovered by ChIP-chip, 12 PPAR $\gamma$ enrichment regions were subcloned into a luciferase reporter plasmid, upstream of an SV40 minimal promoter. Upon transfection together with PPAR $\gamma$ and $\mathrm{RXR} \alpha$ expression vectors into $293 \mathrm{~T}$ cells, nine of the 12 reporters displayed PPAR $\gamma$ dependent activity (Supplemental Fig. S3A). The sites were selected to represent a variety of distances to the closest TSS, ranging from -134 to $+44 \mathrm{~kb}$. No correlation was found between distance and activity. Three of the reporter constructs were analyzed further by electroporation into mature 3T3-L1 adipocytes, and all three were able to drive luciferase activity (Supplemental Fig. S3B). These findings suggest that many of the novel PPAR $\gamma$ binding sites are potentially functional, including sites that are $>100 \mathrm{~kb}$ away from the TSS.

To investigate the relationship between distal PPAR $\gamma$ binding and histone modification, ChIP-chip for acetylated Lys 9 on histone 3 (H3K9ac) was performed using a custom array containing 740 PPAR $\gamma$-binding sites located $>10 \mathrm{~kb}$ from a TSS. H3K9Ac, which is a well-documented signature of enhancers (Roh et al. 2007), was markedly enriched in the vicinity of PPAR $\gamma$ binding (Fig. 1C). Furthermore, H3K9Ac occupancy was increased in $67 \%$ (498 out of 740 ) of the PPAR $\gamma$-binding regions in adipocytes compared to preadipocytes $(P=1.30 \mathrm{e}-31$ by paired $t$-test). Thus, the adipocyte specificity and physical proximity of H3K9Ac enrichment to PPAR $\gamma$ binding suggest a functional relationship.

The vast majority of PPAR $\gamma$ binding occurs along with $R X R \alpha$

Although it is believed that PPAR $\gamma$ binds DNA as a heterodimer with $\operatorname{RXR} \alpha$, it is unclear whether this pattern of binding applies to all PPAR $\gamma$ sites in living cells. ChIP-chip for PPAR $\gamma$ and $\operatorname{RXR} \alpha$ using the custom "PPAR $\gamma$-binding site" arrays described above revealed nearly identical binding patterns such that of the 1370 locations bound by PPAR $\gamma$ on these arrays, 1347 (98.3\%) also had binding for $\operatorname{RXR} \alpha$ (Fig. 2A). The specificity of the $\operatorname{RXR} \alpha$ ChIP-chip was confirmed with an additional antibody raised against a different region of the protein, which demonstrated that $96 \%$ of the RXR $\alpha$-binding sites identified initially were also enriched with the second antibody (Supplemental Fig. S4A). The RXR $\alpha$ ChIP-chip results were further validated by ChIP-QPCR (Supplemental Fig. S4B). As an important control, only $\mathrm{RXR} \alpha$ was recruited to the LXR response element in the fatty acid synthase promoter (Joseph et al. 2002; Matsukuma et al. 2007), which PPAR $\gamma$ does not bind (Supplemental Fig. S4B), indicating that the colocalization observed on PPAR $\gamma$ sites is not due to antibody cross-reactivity.

\section{PPAR $\gamma$ binding occurs primarily at DR1 consensus sites}

Since PPAR $\gamma$ and RXR $\alpha$ colocalize at the PPAR $\gamma$-binding regions, we examined whether the sites contain DR1 elements. For this purpose we scanned the sequences of the PPAR $\gamma$-binding regions using position weight matri- 
A

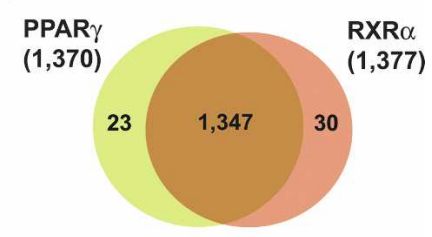

B

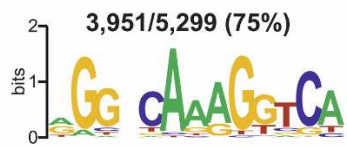

C

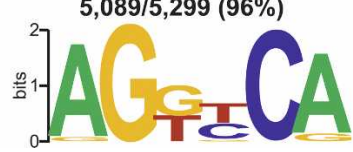

Figure 2. $\operatorname{RXR} \alpha$ heterodimerization and DR1 enrichment at novel PPAR $\gamma$-binding sites. (A) Overlap in binding between $\operatorname{PPAR} \gamma$ and RXR $\alpha$ across 1431 PPAR $\gamma$-binding regions identified previously in the genome-wide search and interrogated in the custom "PPAR $\gamma$-binding site" arrays. Shown in parentheses is the number of enriched regions for each antibody. $(B, C)$ Enriched motif analysis of the PPAR $\gamma$ sites using TRANSFAC and JASPAR PWMs. (B) A DR1-like element was found in $75 \%$ of the sites. (C) Ninety-six percent of the novel PPAR $\gamma$-binding regions contain at least the half site of the consensus PPAR $\gamma$ response element.

ces (PWMs) for known transcription factors from the TRANSAC and JASPAR databases (see Materials and Methods), with the entire mouse genome as a background model. The highest scoring motifs in this analysis represented different DR1 matrices enriched 3.7-9.5fold over what is expected from the frequency of the motifs in the genome. Of the 5299 PPAR $\gamma$-binding regions that we identified, 3951 (75\%) contain a DR1 element (Fig. 2B), and $>95 \%$ of all regions contain a consensus half-site (Fig. 2C). Together with the high degree of colocalization with $\operatorname{RXR} \alpha$, this suggests that in living cells the heterodimer binds to DR1 elements, although one of the half-sites may be highly degenerate. Importantly, the DR1 element is predicted to occur in excess of 600,000 times in the mouse genome, whereas the PPAR $\gamma$ cistrome described here contains $<1 \%$ of that number as sites of actual recruitment. Thus, there is selectivity for the DR1 sites that are actually occupied by PPAR $\gamma$.

\section{Enrichment of the C/EBP-binding motif} at the majority of novel PPAR $\gamma$-binding regions

Having identified the DR1 motif at PPAR $\gamma$-binding sites, we next asked whether binding elements for other transcription factors were present nearby. This analysis determined that the consensus motif for C/EBP factors was highly enriched within the PPAR $\gamma$-binding regions such that $91 \%$ of the genomic regions bound by PPAR $\gamma$ contain at least one C/EBP motif (Fig. 3A). ChIP-QPCR for the most abundant C/EBP isoform in adipocytes,
$\mathrm{C} / \mathrm{EBP} \alpha$, demonstrated that $\mathrm{C} / \mathrm{EBP} \alpha$ was indeed present near a number of PPAR $\gamma$-binding regions with $\mathrm{C} / \mathrm{EBP}$ motifs identified computationally (Fig. 3B).

Genome-wide analysis of $C / E B P \alpha$ binding in adipocytes reveals widespread overlap with PPARy

The preceding analyses suggested that $\mathrm{C} / \mathrm{EBP} \alpha$ binding in adipocytes overlaps that of PPAR $\gamma$ to an extraordinary degree. This was directly tested by genome-wide ChIPchip to determine the $\mathrm{C} / \mathrm{EBP} \alpha$ cistrome in adipocytes. Two biological replicates for $\mathrm{C} / \mathrm{EBP} \alpha \mathrm{ChIP}$-chip were analyzed using MAT, normalizing the data to IgG controls. Using the stringent cutoffs of false discovery rate $\leq 1 \%$ and enrichment of C/EBP $\alpha$ signal over IgG twofold or more, $\mathrm{C} / \mathrm{EBP} \alpha$ binding was detected at 16,760 unique locations (Supplemental Table 2). Analysis of the $\mathrm{C} / \mathrm{EBP} \alpha$ data set relative to known genes revealed that, like PPAR $\gamma, \mathrm{C} / \mathrm{EBP} \alpha$ was predominantly localized to distal intergenic regions and introns, with relatively few sites present in proximal promoters (Fig. 4A). The distribution of binding regions relative to TSSs was also very similar for the two factors (Supplemental Fig. S5). Examination of binding at the Cebpa, Fabp4/aP2, and Pdk4 (pyruvate dehydrogenase kinase, isoenzyme 4) genes illustrates that, as for PPAR $\gamma, \mathrm{C} / \mathrm{EBP} \alpha$ binding occurs in clusters (Fig. 4B). Finally, CEAS was used to show that there is a high degree of conservation of $\mathrm{C} / \mathrm{EBP} \alpha$ and PPAR $\gamma$ sites among higher eukaryotes (Fig. 4C), suggesting that the findings are likely to be relevant across species.

With the elucidation of the PPAR $\gamma$ and $\mathrm{C} / \mathrm{EBP} \alpha$ adipo-

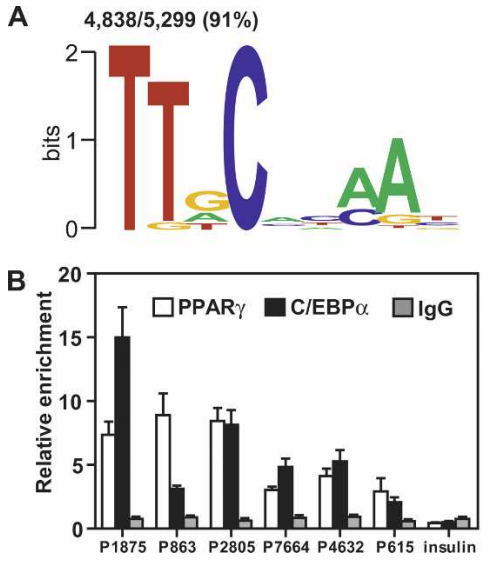

Figure 3. C/EBP response elements are found at the vast majority of PPAR $\gamma$-binding regions. (A) Enrichment of C/EBP motifs. The PPAR $\gamma$-binding locations were mined as in Figure 2, B and C. Shown is the logo of one C/EBP PWM among several that were enriched. (B) ChIP-QPCR analysis for C/EBP $\alpha$ and PPAR $\gamma$ at several novel PPAR $\gamma$-binding regions that were computationally predicted to contain C/EBP response elements (see Supplemental Tables 1 and 5 for identification and location of the PPAR $\gamma$-binding sites). An area of the insulin gene served as negative control for PPAR $\gamma$ and $\mathrm{C} / \mathrm{EBP} \alpha$ binding. Data are normalized to a site in the $A r b p / 36 b 4$ gene and presented as mean $\pm \mathrm{SE}, n=3$. 
A
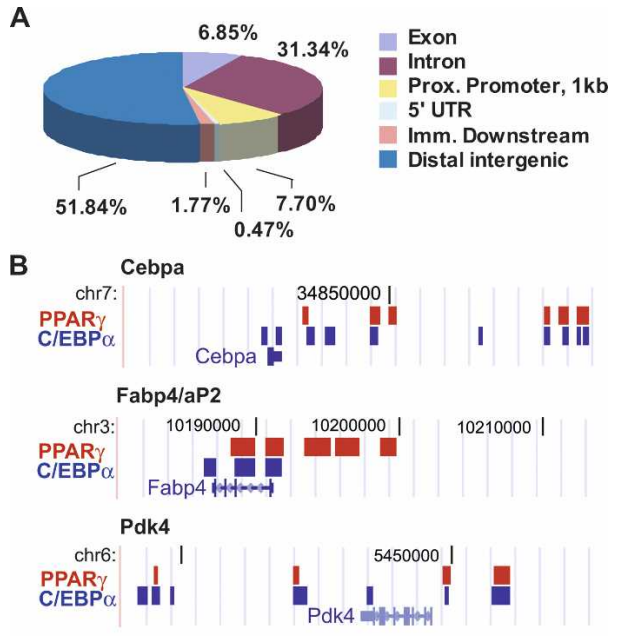

C

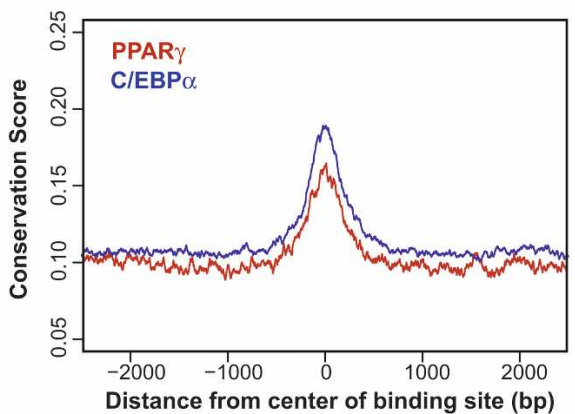

Figure 4. Location analysis of $\mathrm{C} / \mathrm{EBP} \alpha$ binding. $(A)$ Mapping of $\mathrm{C} / \mathrm{EBP} \alpha$-binding regions on genome-wide scale relative to RefSeq mouse genes. The analysis was performed as in Figure 1A. (B) C/EBP $\alpha$ and PPAR $\gamma$ binding in relation to three target genes, Cebpa, Fabp4/aP2, and Pdk4. The genes are shown as in Figure 1B, in the native chromosomal locations according to the mm8 Assembly in the UCSC Genome Browser (http:// genome.ucsc.edu). Blue blocks represent regions of $\mathrm{C} / \mathrm{EBP} \alpha$ enriched ChIP signal, while red blocks represent PPAR $\gamma$ enrichment. (C) Average plot for conservation of all PPAR $\gamma$ - and $\mathrm{C} / \mathrm{EBP} \alpha$-binding regions among higher eukaryotes.

cyte cistromes, the extent to which their binding overlapped could be assessed in an unbiased manner. PPAR $\gamma$ and $\mathrm{C} / \mathrm{EBP} \alpha$ binding overlap was generated in the University of California at Santa Cruz (UCSC) Genome Browser (http://genome.ucsc.edu) (Kent et al. 2002; Karolchik et al. 2004), such that sites were considered overlapping if there was at least $1 \mathrm{bp}$ in common between the binding regions, which average $\sim 1000 \mathrm{bp}$ in length. Remarkably, and in agreement with the bioinformatics predictions, C/EBP $\alpha$ binds nearby at $>60 \%$ of the locations bound by PPAR $\gamma$ (Fig. 5A). Several regions expected to have binding for both PPAR $\gamma$ and C/EBP $\alpha$ or each of the factors alone were validated using ChIPQPCR with two different C/EBP $\alpha$ antibodies, ruling out the possibility of cross-reactivity of the $\mathrm{C} / \mathrm{EBP} \alpha$ antibody with PPAR $\gamma$ (Supplemental Fig. S6).

The functional significance of nearby binding of PPAR $\gamma$ and C/EBP $\alpha$ was addressed by examination of the genes located near overlapping regions. For each PPAR $\gamma$ region that overlaps with $\mathrm{C} / \mathrm{EBP} \alpha$ binding, the nearest gene was determined as well as the distance from the TSS to the center of the PPAR $\gamma$-binding region. Gene Ontology analysis of the closest genes identified by this approach revealed strong enrichment of metabolic processes, such as fatty acid and carboxylic acid metabolism, lipid biosynthesis, carbohydrate biosynthesis, and others (Fig. 5B). The analysis shown was performed for the 1996 sites whose nearest gene was within $50 \mathrm{~kb}$, and was minimally affected by changing the cutoff to 20 or $100 \mathrm{~kb}$. These findings suggest that both PPAR $y$ and $\mathrm{C} / \mathrm{EBP} \alpha$ may be necessary for expression of adipocytespecific genes.

To explore this possibility further, $\operatorname{PPAR} \gamma$ and $\mathrm{C} / \mathrm{EBP} \alpha$ binding was examined relative to expression of genes regulated during adipogenesis. Microarray profiling of preadipocytes and mature adipocytes identified 834 genes up-regulated threefold or more and 877 genes down-regulated threefold or more $(P \leq 0.001)$ during the

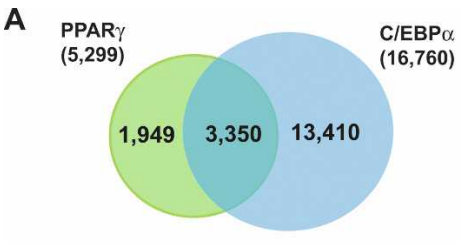

B Summary of Gene Ontology Categories \begin{tabular}{lr}
\hline GO biological process & p Value \\
\hline \hline & \\
Cellular lipid metabolism & $2.00 \mathrm{E}-12$ \\
Fatty acid metabolism & $2.00 \mathrm{E}-10$ \\
Carboxylic acid metabolism & $5.20 \mathrm{E}-09$ \\
Lipid biosynthesis & $1.10 \mathrm{E}-07$ \\
Carbohydrate biosynthesis & $1.80 \mathrm{E}-05$ \\
Cellular carbohydrate metabolism & $5.00 \mathrm{E}-05$ \\
Regulation of multicellular organism growth & $2.00 \mathrm{E}-04$ \\
Regulation of programmed cell death & $2.10 \mathrm{E}-04$ \\
Regulation of apoptosis & $2.70 \mathrm{E}-04$ \\
Monosaccharide metabolism & $2.80 \mathrm{E}-04$ \\
Organ development & $3.00 \mathrm{E}-04$ \\
Mitochondrion organization and biosynthesis $3.20 \mathrm{E}-04$ \\
\hline${ }^{*}$ p Value was calculated using Fisher Exact statistics.
\end{tabular}

C

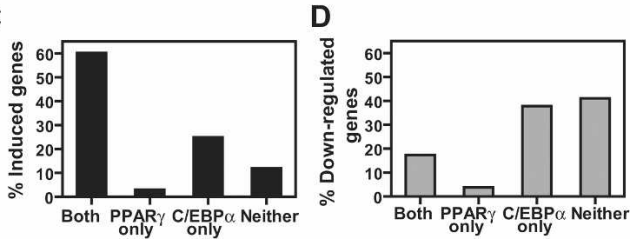

Figure 5. Extent of PPAR $\gamma$ and $\mathrm{C} / \mathrm{EBP} \alpha$ binding overlap and its association with gene expression during adipocyte differentiation. (A) Overlap between the binding of PPAR $\gamma$ and C/EBP $\alpha$ on genome-wide scale. Shown are the numbers of regions found to be shared by the two factors-i.e., having at least $1 \mathrm{bp}$ in common-or unique to each factor. (B) Summary of gene ontology (GO) categories of the nearest genes to regions with overlapping $\operatorname{PPAR} \gamma$ and $\mathrm{C} / \mathrm{EBP} \alpha$ binding. In this analysis, only binding regions whose nearest gene was within $50 \mathrm{~kb}$ were considered. $(C)$ Association between factor binding and genes induced in adipogenesis. Shown are the percent genes up-regulated more than threefold and containing binding sites within $50 \mathrm{~kb}$ of the gene start site for both factors (Both), PPAR $\gamma$ alone, C/EBP $\alpha$ alone, or neither factor (Neither). (D) The association between genes down-regulated in adipocyte differentiation and PPAR $\gamma$ and $\mathrm{C} / \mathrm{EBP} \alpha$ binding was analyzed as in $C$. 
differentiation process (Supplemental Tables 3, 4). Remarkably, $>60 \%$ of the up-regulated genes had binding for both PPAR $\gamma$ and C/EBP $\alpha$ within $50 \mathrm{~kb}$ of their TSSs, while only $3 \%$ of the genes were bound by PPAR $\gamma$ alone (Fig. 5C). By contrast, the down-regulated genes were not enriched for binding of both factors (Fig. 5D), indicating that the colocalization of PPAR $\gamma$ and $\mathrm{C} / \mathrm{EBP} \alpha$ is unique to genes that are highly induced in adipogenesis. Furthermore, there was little change in the fraction of genes bound by $\mathrm{C} / \mathrm{EBP} \alpha$ alone (Fig. 5C,D). Importantly, increasing the threshold distance from $50 \mathrm{~kb}$ up to $100 \mathrm{~kb}$ in $10 \mathrm{~kb}$ intervals did not significantly alter the percentage of genes with binding sites (Supplemental Fig. S7), suggesting that no bias had been introduced by setting the distance at $50 \mathrm{~kb}$.

\section{$C / E B P S$ are required for the expression of genes bound} by PPAR $\gamma$ and $C / E B P \alpha$

To assess whether binding of $\mathrm{C} / \mathrm{EBP} \alpha$ is required for the expression of genes bound by both PPAR $\gamma$ and $\mathrm{C} / \mathrm{EBP} \alpha$, each transcription factor was depleted from mature adipocytes using siRNA (Fig. 6A). Surprisingly, knockdown of $\mathrm{C} / \mathrm{EBP} \alpha$ produced small changes in the mRNA levels of target genes such as adiponectin and $a P 2$, which are well-characterized C/EBP $\alpha$ targets (Fig. 6B; Christy et al. 1989; Park et al. 2004). We hypothesized that this may be due to compensation by $\mathrm{C} / \mathrm{EBP} \beta$, which has been reported to be present and active in differentiated adipocytes (MacDougald et al. 1995). Indeed, ChIP-QPCR in mature adipocytes revealed $\mathrm{C} / \mathrm{EBP} \beta$ binding to several newly discovered and previously known C/EBP targets (Supplemental Fig. S8A). This was confirmed on a larger scale using the custom "PPAR $\gamma$-binding site" arrays described earlier. $\mathrm{C} / \mathrm{EBP} \alpha$ binding was found near many of the PPAR $\gamma$-binding sites, such that 1117 out of 1370 PPAR $\gamma$-occupied regions also had $\mathrm{C} / \mathrm{EBP} \alpha$ binding, as can be seen on the Cd36 gene (Supplemental Fig. S8B). ChIP-chip for C/EBP $\beta$ and C/EBP $\alpha$ showed nearly identical binding profiles, with 1140 out of 1150 (99.1\%) $\mathrm{C} / \mathrm{EBP} \alpha$ locations also bound by C/EBP $\beta$ (Supplemental Fig. $\mathrm{S} 8 \mathrm{C}, \mathrm{D})$. The $\mathrm{C} / \mathrm{EBP} \alpha$ and $\mathrm{C} / \mathrm{EBP} \beta$ antibodies were shown to be specific by immunoblotting, ruling out an artifact due to antibody cross-reactivity (Supplemental Fig. S9A). The specificity of C/EBP $\alpha$ and $\mathrm{C} / \mathrm{EBP} \beta$ binding was confirmed further by ChIP-chip using additional antibodies and the custom array containing 740 PPAR $\gamma$ binding regions. Importantly, the vast majority of sites initially identified on this array for $\mathrm{C} / \mathrm{EBP} \alpha$ and $\mathrm{C} / \mathrm{EBP} \beta$ were validated with the new antibodies (Supplemental Fig. S9B,C), indicating that the binding results are robust regardless of the antibody used for ChIP.

Thus, $\mathrm{C} / \mathrm{EBP} \beta$ and $\mathrm{C} / \mathrm{EBP} \alpha$ are bound to $\mathrm{C} / \mathrm{EBP}$ sites in mature adipocytes, suggesting that these factors act redundantly. Because knockdown of C/EBP $\beta$ gave similar results in target gene expression as $\mathrm{C} / \mathrm{EBP} \alpha($ Fig. $6 \mathrm{~B})$, the effect of simultaneous depletion of $\mathrm{C} / \mathrm{EBP} \alpha$ and $\mathrm{C} / \mathrm{EBP} \beta$ was examined. Importantly, the expression levels of several genes shown to be co-occupied by PPAR $\gamma$ and $\mathrm{C} / \mathrm{EBP} \alpha$ were substantially reduced in the absence of both $\mathrm{C} / \mathrm{EBP} \alpha$ and C/EBP $\beta$ (Fig. $6 \mathrm{~B}$ ). To rule out the possibility that the small decrease in PPAR $\gamma$ levels produced by C/EBP knockdown (see Fig. 6A) is responsible for the
Figure 6. Effects of C/EBP depletion on expression of genes on which PPAR $\gamma$ and the C/EBPs colocalize. $(A)$ Immunoblot analysis demonstrating the efficiency of siRNA-mediated knockdown of $\mathrm{C} / \mathrm{EBP} \alpha, \mathrm{C} / \mathrm{EBP} \beta$, $\operatorname{PPAR} \gamma$, or nontarget contol (NTC). HDAC2 represents a loading control. (B) QPCR analysis of gene expression following $24 \mathrm{~h}$ of siRNA-mediated knockdown. All of the genes shown were found to have binding sites for PPAR $\gamma$ and $\mathrm{C} / \mathrm{EBP} \alpha$, except eukaryotic translation elongation factor $1 \propto 1(E e f 1 \alpha 1)$ and 36b4, which were used as controls. Data were normalized to the housekeeping gene Pabpc1, and are presented as mean $\pm \mathrm{SE}, n=3$. (C$E$ ) ChIP-QPCR analysis of factor binding at several target sites following $24 \mathrm{~h}$ of $\mathrm{C} / \mathrm{EBP} \alpha$ and $\beta$ or NTC knockdown. Data are normalized to a nontarget genomic site and IgG enrichment. Shown is a representative ChIPQPCR experiment. (C) PPAR $\gamma$ enrichment. $(D) \mathrm{C} / \mathrm{EBP} \alpha$ enrichment. (E) C/EBP $\beta$ enrichment. (F) QPCR analysis of gene expression following $24 \mathrm{~h}$ of siRNA-mediated knockdown of PPAR $\gamma$ alone and together with C/EBP $\alpha$ and C/EBP $\beta$. Analysis was performed as in $B$ above.
A

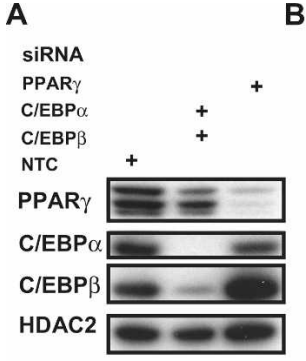

C

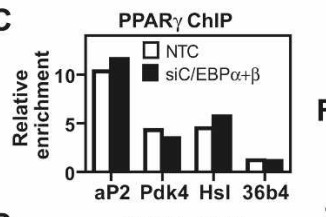

D C/EBP $\alpha$ ChIP

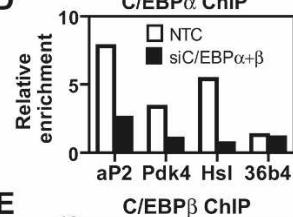

E

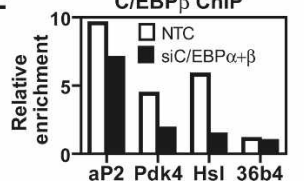

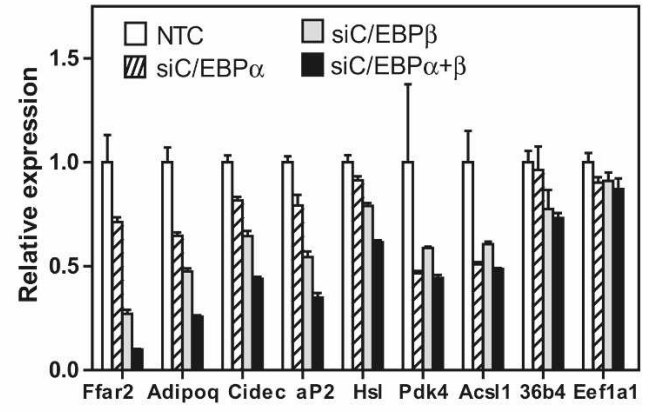

F

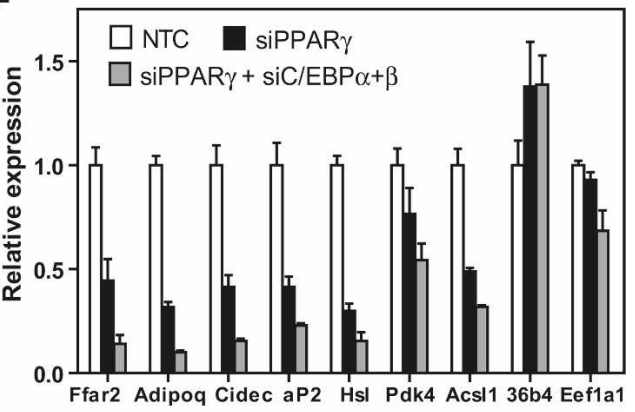


effects on gene expression, we examined the recruitment of PPAR $\gamma$ to a number of binding sites in conditions of $\mathrm{C} / \mathrm{EBP} \alpha$ and $\beta$ depletion. There was little or no decrease in occupancy compared to control cells (Fig. 6C), suggesting that the transcriptional activity of PPAR $\gamma$ is unlikely to be altered under these conditions. On the other hand, $\mathrm{C} / \mathrm{EBP} \alpha$ and $\beta$ knockdown produced the expected decreases in occupancy by these factors at the same target sites (Fig. 6D,E). Similarly, PPAR $\gamma$ knockdown led to a substantial reduction of PPAR $\gamma$ recruitment (Supplemental Fig. S10A) and very little change in C/EBP $\beta$ occupancy (Supplemental Fig. S10B), although C/EBP $\alpha$ binding was somewhat decreased (Supplemental Fig. S10C). As expected, PPAR $\gamma$ knockdown led to downregulation of target genes within $24 \mathrm{~h}$ of siRNA electroporation (Fig. 6F). However, the effects on gene expression were substantially larger when PPAR $\gamma$ and both C/EBPs were simultaneously depleted (Fig. 6F), suggesting that the factors have synergistic roles in activating transcription. Taken together, these data demonstrate that the C/EBPs not only bind near PPAR $\gamma$ at genes induced during adipogenesis, but also cooperate with $\operatorname{PPAR} \gamma$ to regulate the expression of these genes in adipocytes.

\section{Discussion}

In this study, an unbiased approach was taken to characterize the PPAR $\gamma$ cistrome in mouse 3T3-L1 adipocytes. Five thousand two hundred ninety-nine genomic binding sites were identified with a high degree of confidence. Investigation of the mechanism by which PPAR $\gamma$ associates with these sites led to a number of discoveries about global PPAR $\gamma$ function. PPAR $\gamma$ binds primarily far from TSS, and typically associates with DR1 elements as a heterodimer with $\operatorname{RXR} \alpha$. Importantly, a new level of collaboration between PPAR $\gamma$ and C/EBP factors was uncovered, which involves colocalization at a surprisingly large number of target genes. Thus, the current study advances understanding of $\operatorname{PPAR} \gamma$-dependent gene regulation in adipocytes by identifying a large number of novel binding sites and potential gene targets. It also highlights the fact that rather than functioning separately, PPAR $\gamma$ and other factors such as the C/EBPs are likely part of a complex transcriptional network that regulates gene expression in spatially and temporally coordinated manner.

PPAR $\gamma$ binding occurs primarily in distal intergenic regions and introns, with few sites localizing to proximal promoters. This distribution is consistent with what has been shown for other transcription factors, including estrogen receptor (Carroll et al. 2006), androgen receptor (Bolton et al. 2007), and FoxA1 (Lupien et al. 2008). Such findings underscore the advantages of whole-genome approaches and the limitations of current methods searching for factor binding within gene promoters, including promoter bashing and promoter tiling arrays. In fact, a recent study involving adipocyte PPAR $\gamma$ ChIP and hybridization to a proximal promoter tiling array discov- ered only 167 binding sites while interrogating 16,592 promoters (Nakachi et al. 2008).

A potential concern about sites located tens and hundreds of kilobases away from TSS is their functionality. However, a large number of PPAR $\gamma$-binding regions located $>10 \mathrm{~kb}$ from a TSS were enriched for H3K9Ac in adipocytes but not preadipocytes, suggesting that PPAR $\gamma$ bound at such sites may be recruiting histone acetyltransferases. Furthermore, the ability of $12 \operatorname{PPAR} \gamma$-binding regions tested to function as enhancer elements was independent of distance to the nearest gene in the context of a minimal promoter. Similar results have been reported for other nuclear receptors such as vitamin D (Kim et al. 2007), estrogen (Carroll et al. 2005), and glucocorticoid receptors (Anderson et al. 2007). To explain the abundance of distal binding sites, it has been proposed that transcription factors bound to distal sites direct DNA looping such that coactivators and chromatin remodelers at the distal enhancers are brought in proximity to TSS of target genes, facilitating the recruitment of polymerase (West and Fraser 2005). Such communication between enhancers and promoters has been demonstrated for many factors including androgen receptor (Wang et al. 2005), and estrogen receptor (Carroll et al. 2005). Similarly, PPAR $\gamma$ may also be able to orchestrate DNA looping as a mechanism of long-range gene regulation, which would account for the presence of large numbers of distal PPAR $\gamma$-binding sites. Further understanding of PPAR $\gamma$ action will involve characterizing its role in long-range chromatin interactions and elucidating the mechanism by which such high-order chromatin structures lead to active transcription.

Using a custom array of PPAR-binding sites, $\mathrm{RXR} \alpha$ recruitment was observed at $\sim 98 \%$ of adipocyte PPAR $\gamma$ binding locations. This strongly suggests that PPAR $\gamma$ heterodimerizes with $\operatorname{RXR} \alpha$ at most if not all of its binding sites in adipocytes, although binding of RXR as a homodimer at some locations cannot be excluded (IJpenberg et al. 2004). The PPAR $\gamma / \operatorname{RXR} \alpha$ binding occurred predominantly at DR1 elements, although some of these sites vary substantially from the consensus. The composite motif derived from in vivo DR1 elements illustrates that the spacer position favors adenosine, and the $3^{\prime}$ half-site is more highly conserved. This is consistent with observations in vitro that $\operatorname{RXR} \alpha$, which occupies the 3' half-site (DiRenzo et al. 1997), has higher sequence stringency compared to PPAR $\gamma$ occupying the $5^{\prime}$ site (Temple et al. 2005). Although previous studies have suggested the existence of a conserved extended $5^{\prime}$ sequence (IJpenberg et al. 1997; Temple et al. 2005), we did not find a strong preference. This does not rule out the possibility that within relatively degenerate DR1 elements there is a subset for which the flanking positions are better conserved, for example, to enhance low-affinity PPAR $\gamma$ binding (IJpenberg et al. 1997).

A surprising discovery in this study was that C/EBP motifs are present within $91 \%$ of the PPAR $\gamma$-binding regions. Genome-wide ChIP-chip was used to demonstrate that $\mathrm{C} / \mathrm{EBP} \alpha$ binding overlaps with $>60 \%$ of the PPAR $\gamma$ target locations. Gene ontology analysis of the nearest 
genes for such overlapping sites revealed a substantial enrichment for lipid metabolism processes. Combining the binding data with an expression microarray from adipocyte differentiation revealed that $60 \%$ of the up-regulated genes have binding sites for both PPAR $\gamma$ and $\mathrm{C} / \mathrm{EBP} \alpha$ within $50 \mathrm{~kb}$ of the TSS. This suggests that the colocalization of PPAR $\gamma$ and $\mathrm{C} / \mathrm{EBP} \alpha$ occurs specifically at genes that are activated in differentiation and participate in major adipocyte-specific functions such as triglyceride synthesis and lipid storage. Consistent with previous reports (MacDougald et al. 1995), we also found that $\mathrm{C} / \mathrm{EBP} \beta$ continues to occupy $\mathrm{C} / \mathrm{EBP}$ sites even in mature adipocytes. Knockdown of PPAR $y$ or the combination of $\mathrm{C} / \mathrm{EBP} \alpha$ and $\beta$ clearly showed that both sets of factors are essential for optimal expression of adipocyte genes. Furthermore, simultaneous knockdown of the three factors even more dramatically decreases the expression of a number of genes, suggesting that there may be a large class of genes for which PPAR $\gamma$ and the C/EBPs play synergistic roles for activation.

These findings suggest a much more prominent role for $\mathrm{C} / \mathrm{EBP}$ factors in mature adipocytes than has been appreciated. Because the C/EBP cistrome in adipocytes was previously unknown, it was believed that C/EBP $\beta$ function is limited to early adipogenesis, while the role of $\mathrm{C} / \mathrm{EBP} \alpha$ is to maintain PPAR $\gamma$ expression and insulin sensitivity in mature cells (Wu et al. 1999; Elberg et al. 2000; Rosen et al. 2002). In contrast, the present data suggest that the majority of adipocyte genes are not regulated by $\operatorname{PPAR} \gamma$ alone but rather require $\mathrm{C} / \mathrm{EBP} \alpha$ and $\mathrm{C} / \mathrm{EBP} \beta$ binding as well. The extent of this collaboration could not have been predicted from previous findings since until now only a small number of genes were known to have binding sites for both factors. Thus, by characterizing the widespread colocalization of the factors and its functional significance in metabolic gene expression, the current findings contribute to understanding the mechanism by which PPAR $\gamma$ and C/EBPs cooperatively regulate adipocyte biology.

Although the molecular details of this cooperation remain to be elucidated, it is possible that the ability of each factor to recruit coactivators and chromatin remodelers at adjacent sites leads to synergistic effects on transcriptional activation. Alternatively, the presence of one factor may facilitate binding of the other; for example, by opening chromatin and making binding sites accessible. In this sense, $\mathrm{C} / \mathrm{EBP} \beta$, which is activated earlier in adipogenesis than either PPAR $\gamma$ or $\mathrm{C} / \mathrm{EBP} \alpha$, may serve as a pioneer factor that directs changes in chromatin marks and nucleosome positioning allowing the other factors to bind when they are expressed. In fact, it has been proposed that $\mathrm{C} / \mathrm{EBP} \beta$ is bound to promoters of genes such as Cebpa prior to transcriptional activation, and it is associated with corepressors and histone deacetylases, which are displaced upon activation of PPAR $\gamma$, allowing for gene expression to occur (Zuo et al. 2006). Finally, it is likely that PPAR $\gamma$ and the C/EBPs bind in proximity to other transcription factors that remain to be characterized and may enhance or antagonize transcriptional activity. Future studies are necessary to characterize the chromatin context in which PPAR $\gamma$ and C/EBP binding occurs, including histone modification profiles, binding site accessibility, as well as recruitment of cofactors, chromatin- and histone-modifying machinery, and other transcription factors.

\section{Materials and methods}

\section{Cell culture}

3T3-L1 preadipocytes were obtained from American Type Culture Collection and grown to confluence in growth medium consisting of high-glucose DMEM (Invitrogen) supplemented with $10 \%$ fetal bovine serum (U.S. Biotechnologies) and 100 $\mathrm{U} / \mathrm{mL}$ penicillin and $100 \mu \mathrm{g} / \mathrm{mL}$ streptomycin (Invitrogen). Two days post-confluence, differentiation medium was added, consisting of growth medium supplemented with $1 \mu \mathrm{M}$ dexamethasone, $10 \mu \mathrm{g} / \mathrm{mL}$ bovine insulin, and $0.5 \mathrm{mM}$ isobutyl-1-methylxanthine (Sigma). Cells were grown in differentiation medium for $3 \mathrm{~d}$, followed by $2 \mathrm{~d}$ in growth medium with insulin, followed by growth medium only. $293 \mathrm{~T}$ cells were grown in highglucose DMEM (Invitrogen) supplemented with $10 \%$ fetal bovine serum (U.S. Biotechnologies), $100 \mathrm{U} / \mathrm{mL}$ penicillin and 100 $\mu \mathrm{g} / \mathrm{mL}$ streptomycin (Invitrogen).

\section{ChIP}

Cells were cross-linked in $1 \%$ Formaldehyde (Fisher) for $10 \mathrm{~min}$, followed by quenching with $1 / 20$ volume of $2.5 \mathrm{M}$ glycine solution, and two washes with $1 \times$ PBS. Nuclear extracts were prepared by dounce homogenizing in nuclear lysis buffer $(20$ mM HEPES, $0.25 \mathrm{M}$ sucrose, $3 \mathrm{mM} \mathrm{MgCl}{ }_{2}, 0.2 \% \mathrm{NP}-40,3 \mathrm{mM}$ $\beta$-mercaptoethanol, 0.4 mM PMSF, Complete protease inhibitor tablets from Roche). Chromatin fragmentation was performed by sonication in ChIP SDS lysis buffer (50 mM HEPES, $1 \%$ SDS, 10 mM EDTA), using Bioruptor (Diagenode). Proteins were immunoprecipitated in ChIP dilution buffer $(50 \mathrm{mM}$ Hepes/NaOH at ph 7.5, $155 \mathrm{mM} \mathrm{NaCl}, 1.1 \%$ Triton $\mathrm{X}-100,0.11 \% \mathrm{Na}$-deoxycholate, $1 \mathrm{mM}$ PMSF, Complete protease inhibitor tablet), using anti-C/EBP $\alpha$ antibodies (sc-61 and sc-9314, Santa Cruz Biotechnologies), anti-PPAR $\gamma$ antibodies (sc-7196 and sc-1984, Santa Cruz Biotechnologies; 81b8, Cell Signaling Technologies), antiC/EBP $\beta$ antibodies (sc-746x and sc-150x, Santa Cruz Biotechnologies), anti-RXR $\alpha$ antibodies (sc-553 and sc-774, Santa Cruz Biotechnologies) or nonspecific rabbit IgG control (Sigma). Cross-linking was reversed overnight at $65^{\circ} \mathrm{C}$, and DNA isolated using phenol/chloroform/isoamyl alcohol. For ChIPQPCR, enrichment was measured using Power SYBR Green PCR Mastermix and the PRISM 7500 instrument (Applied Biosystems). Analysis was performed by the standard curve method and normalization to a nontarget control region of the $36 \mathrm{~b} 4$ or insulin genes. Primer sequences used for QPCR analysis can be found in Supplemental Table 5. For acetylation ChIP, an antiH3K9Ac antibody (06-942, Upstate Biotechnologies) and antihistone 3 (H3) antibody (ab1791, Abcam) were used and the ChIP was performed as described previously (Steger et al. 2008).

\section{ChIP-chip}

Whole-genome ChIP-chip was performed using Mouse Tiling 2.0R Array Set (Affymetrix), following ligation-mediated PCR (Lee et al. 2006), limited DNase I (Ambion) digestion to fragment DNA to average size of $\sim 200-300 \mathrm{bp}$, and labeling with biotin (Perkin Elmer). Arrays were hybridized, washed, and scanned as per manufacturer's instructions. The custom 
"PPAR $\gamma$-binding site" arrays contain 1431 PPAR $\gamma$-binding regions from the whole-genome data set. One of the arrays contains 740 distal regions, $\geq 10 \mathrm{~kb}$ away from the TSS of the nearest gene, while the second array contains 691 PPAR $\gamma$-binding regions that are located within $10 \mathrm{~kb}$ of the nearest gene or within the exons of a gene. Regions of enriched PPAR $\gamma$ signal over IgG based on the genome-wide study were centered within $10 \mathrm{~kb}$ of genomic sequence. Their nonrepetitive chromosomal sequence based on the February 2006 Mouse Genome Assembly (mm8) was retrieved from the UCSC Genome Browser (http:// genome.ucsc.edu), and tiled with overlapping 60 mer oligonucleotides. The arrays were printed by Agilent (http://www. agilent.com). For transcription factors, amplification of the ChIP, and input DNA was carried out as above, followed by labeling with Cy5 (ChIP DNA) and Cy3 (input DNA). Hybridization was performed according to manufacturer's protocol and as previously described (Steger et al. 2008). ChIP-chip on the custom arrays was performed in replicate for PPAR $\gamma$ ChIP with 81 b8 antibody, RXR $\alpha$ ChIP with sc-553 antibody, and for IgG. One hybridization was performed for each of the following ChIP experiments: RXR $\alpha$ ChIP with sc-774 antibody, C/EBP $\alpha$ with sc-61 antibody, C/EBP $\alpha$ with sc-9314 antibody, C/EBP $\beta$ with sc-150 antibody, and C/EBP $\beta$ with sc-746 antibody.

\section{ChIP-chip analysis}

Whole-genome arrays were analyzed with MAT (Johnson et al. 2006), with probes remapped to the February 2006 Mouse Genome Assembly (mm8) using xMAN (Li et al. 2008). The threshold cutoffs for binding regions were FDR $\leq 1 \%$, and enrichment of PPAR $\gamma$ or C/EBP $\alpha$ over IgG twofold or more. PPAR $\gamma$ and $\mathrm{C} / \mathrm{EBP} \alpha$ binding overlap was generated in the UCSC Genome Browser (http://genome.ucsc.edu) such that sites were considered overlapping if there was at least $1 \mathrm{bp}$ in common between the binding regions. Screen shots of PPAR $\gamma$ - and C/EBP $\alpha$-binding regions relative to individual RefSeq genes in their native chromosomal locations were obtained from the UCSC Genome Browser. Custom tiling-arrays were analyzed with MA2C (Song et al. 2007), after reformatting of Agilent data files. For transcription factors, the threshold cutoffs for binding regions were a $P$-value $\leq 10^{-3}$. If the center $1 \mathrm{~kb}$ of any given $10-\mathrm{kb}$ tiled region overlapped with an $\mathrm{MA} 2 \mathrm{C}$ peak by at least $100 \mathrm{bp}$, the region was regarded as bound. To generate the average $\mathrm{H} 3 \mathrm{~K} 9 \mathrm{Ac}$ profile, the H3K9Ac signal at each probe was first normalized to $\mathrm{H} 3$ signal. All $10-\mathrm{kb}$ regions were aligned at the center where PPAR $\gamma$ binding occurs, followed by calculation of the average signal for each location. A 500-bp sliding window was used to smooth the profiles and the data were normalized to the average signal in the $1 \mathrm{~kb}$ at each end. For comparison of adipocyte and preadipocyte acetylation, the average H3K9Ac signal for the center $2 \mathrm{~kb}$ of each region was obtained and normalized to the average $\mathrm{H} 3$ signal in the same $2 \mathrm{~kb}$ area and to the signal in the $1 \mathrm{~kb}$ at each end. The average signals generated for adipocytes and preadipocytes for each region were compared, and paired $t$-test was used to determine whether overall the increase in acetylation signal for adipocytes was significant.

\section{Mapping of binding regions to known genes and conservation analysis}

The distribution of PPAR $\gamma$ - and C/EBP $\alpha$-binding sites relative to known genes was generated using CEAS (Ji et al. 2006) according to gene coordinates in the February 2006 Mouse Genome Assembly $(\mathrm{mm} 8)$. For each data set, the ChIP regions were aligned at the center and uniformly expanded to $2500 \mathrm{bp}$ at each end, and at each position the average phastCons score (Siepel et al. 2005) retrieved from UCSC Genome Browser (http://genome.ucsc.edu) was generated for the average conservation plot.

\section{Enriched motif analysis}

An updated version of CEAS (Ji et al. 2006) was used to obtain the enriched transcription factor motifs located in ChIP regions. The 526 well-defined PWMs used in the analysis were from TRANSFAC (Matys et al. 2003) and JASPAR (Sandelin et al. 2004). The enrichment of motifs within the PPAR $\gamma$ ChIP-chip data set was calculated relative to the frequency of motif occurrence in the entire mouse genome.

\section{Nearest gene analysis}

For each $\operatorname{PPAR} \gamma$ - or $\mathrm{C} / \mathrm{EBP} \alpha$-binding region, the nearest gene was determined, and the distance from the center of the binding region to the TSS of the gene was calculated based on the February 2006 Mouse Genome Assembly (mm8). Gene Ontology (GO) analysis was performed using DAVID (http://david.abcc.ncifcrf.gov) (Dennis et al. 2003), by examining the biological processes in which nearest genes are involved, using RefSeq mRNA IDs and the entire mouse genome as a background model. $P$-values were calculated using Fisher Exact statistics. The GO analysis was performed for the 1996 PPAR $\gamma$ regions with overlapping $\mathrm{C} / \mathrm{EBP} \alpha$ binding and distance to the nearest gene $\leq 50 \mathrm{~kb}$. Changing the cutoff to 20 or $100 \mathrm{~kb}$ did not substantially alter the GO analysis outcome.

Association between gene expression changes during adipocyte differentiation and PPAR $\gamma$ and $C / E B P \alpha$ binding

Genes having PPAR $\gamma$ or $\mathrm{C} / \mathrm{EBP} \alpha$ binding within certain distance were defined as those having at least one binding region within the distance relative to the TSS. For each category of differentially expressed genes, the percentage of genes having PPAR $\gamma$ - or $\mathrm{C} / \mathrm{EBP} \alpha$-binding regions within $10-100 \mathrm{~kb}$ was calculated. The location distributions of PPAR $\gamma$ or $\mathrm{C} / \mathrm{EBP} \alpha$ sites relative to the TSS of all RefSeq genes were also calculated.

\section{Plasmids, transfections, and luciferase reporter assays}

Twelve novel PPAR $\gamma$-binding sites were selected based on distance from nearest TSS. Each 1000-bp enriched region was amplified from genomic NIH 3T3 DNA (primer sequences in Supplemental Table 6) using PfuTurbo Hotstart Polymerase (Stratagene) and cloned into the pCR-Blunt II-TOPO vector (Invitrogen). Following restriction enzyme digest, the regions were inserted into the multiple cloning site of the pGL3-Promoter vector (Promega). 293T cells were transfected overnight with $100 \mathrm{ng}$ of pGL3-Promoter construct, 3 ng of pRL-CMV renilla vector, as well as $50 \mathrm{ng}$ each of pCMX-PPAR $\gamma$ and $\mathrm{pCMX}-\mathrm{RXR} \alpha$, or $100 \mathrm{ng}$ of pCMX empty in 24-well plates using Lipofectamine 2000 (Invitrogen) according to manufacturer's protocol. Luciferase activity was measured using Dual Luciferase Reporter Assay (Promega), normalizing firefly luciferase to renilla activity. For C/EBP factor overexpression, 293T cells were transfected overnight in 12-well plates with 50 ng of pSG5-C/EBP $\alpha$ or pSG5-C/ EBP $\beta$, or an empty pSG5 vector. For 3T3-L1 transfections, mature adipocytes were detached using Trypsin (Invitrogen) and Collagenase (Roche), washed, resuspended in Buffer V (AMAXA), and mixed with siRNA oligo (Dharmacon) or plasmid DNA. For luciferase assays, $2 \mu \mathrm{g}$ of pGL3-Promoter construct and $6 \mathrm{ng}$ of renilla vector were used per electroporation. For knockdown experiments, 2 or $3 \mathrm{nmol}$ of siRNA oligo per 
transcription factor was used. Where necessary, the electroporation was supplemented with nontarget control (NTC) oligo in order to maintain equivalent quantity of siRNA across treatment groups. All electroporations were performed using Nucleofector II and Cell Line Nucleofector Kit V (AMAXA). The sequences of the siRNA oligos used for transcription factor knockdown are as follows: PPAR $\gamma$, CAACAGGCCUC AUGAAGAAUU; C/EBP $\alpha$, CCUGAGAGCUCCUUGGUCAUU; C/EBPß, GAAAAGAGGCGUAUGUAUAUU.

\section{RNA isolation, QPCR, and gene expression profiling}

RNA was isolated using RNeasy Mini Kit (Qiagen), followed by reverse transcription of $0.2-0.8 \mu \mathrm{g}$ of RNA with the High-Capacity cDNA Reverse Transcription kit (Applied Biosystems) following manufacturer's instructions. QPCR was performed using primers as described (Steger et al. 2008), Power SYBR Green PCR Mastermix (Applied Biosystems), and the PRISM 7500 instrument (Applied Biosystems). Analysis was performed using the standard curve method and normalization of all genes of interest to the housekeeping control Pabpc1. Gene expression profiling was carried out using the MOE430 version 2.0 Mouse Array (Affymetrix) by hybridizing RNA from preadipocytes and mature adipocytes in triplicate.

\section{Gene expression analyses}

The gene expression data were normalized and summarized with RMA algorithm (Irizarry et al. 2003) and an updated RefSeq probe set definition (Dai et al. 2005). Differentially expressed genes were determined by using a $t$-test with a $P$-value $\leq 10^{-3}$ and a fold change $>3$.

\section{Immunoblotting}

Cell protein was extracted on ice in cold whole-cell extract buffer $(0.15 \mathrm{M} \mathrm{NaCl}, 0.05 \mathrm{M}$ Tris at $\mathrm{pH} 7.4,0.005 \mathrm{M}$ EDTA, $0.5 \%$ NP-40) supplemented with Complete protease inhibitors (Roche). SDS-PAGE was performed using 4\%-20\% Tris-glycine gels (Invitrogen), followed by transfer to PVDF membranes (Invitrogen). The primary antibodies used for immunoblotting were as follows: anti-C/EBP $\alpha$ (sc-61, Santa Cruz Biotechnologies), anti-C/EBP $\beta$ (sc-150x, Santa Cruz Biotechnologies), antiPPAR $\gamma$ (sc-7273, Santa Cruz Biotechnologies), anti-HDAC2 (sc7899, Santa Cruz Biotechnologies), and anti-Ran (610,341, BD Biosciences). After incubation with horseradish peroxidase-conjugated secondary antibodies, blots were developed using the enhanced chemiluminescent substrate kit from Amersham.

\section{Acknowledgments}

We thank members of the Lazar laboratory for insightful discussions and reagents, Elisabetta Manduchi (University of Pennsylvania) for help with computational analysis, and Mathieu Lupien and Myles Brown (Dana-Farber Cancer Institute) for helpful discussion. This work was supported by NIH R01 DK4970 (to M.A.L.) and NIH R01 HG004069-02 (to X.S.L.).

\section{References}

Anderson, P.D., Mehta, N.N., Wolfe, M.L., Hinkle, C.C., Pruscino, L., Comiskey, L.L., Tabita-Martinez, J., Sellers, K.F., Rickels, M.R., Ahima, R.S., et al. 2007. Innate immunity modulates adipokines in humans. J. Clin. Endocrinol. Metab. 92: 2272-2279.
Bolton, E.C., So, A.Y., Chaivorapol, C., Haqq, C.M., Li, H., and Yamamoto, K.R. 2007. Cell- and gene-specific regulation of primary target genes by the androgen receptor. Genes \& Dev. 21: 2005-2017.

Cao, Z., Umek, R.M., and McKnight, S.L. 1991. Regulated expression of three C/EBP isoforms during adipose conversion of 3T3-L1 cells. Genes \& Dev. 5: 1538-1552.

Carroll, J.S., Liu, X.S., Brodsky, A.S., Li, W., Meyer, C.A., Szary, A.J., Eeckhoute, J., Shao, W., Hestermann, E.V., Geistlinger, T.R., et al. 2005. Chromosome-wide mapping of estrogen receptor binding reveals long-range regulation requiring the forkhead protein FoxA1. Cell 122: 33-43.

Carroll, J.S., Meyer, C.A., Song, J., Li, W., Geistlinger, T.R., Eeckhoute, J., Brodsky, A.S., Keeton, E.K., Fertuck, K.C., Hall, G.F., et al. 2006. Genome-wide analysis of estrogen receptor binding sites. Nat. Genet. 38: 1289-1297.

Chawla, A., Schwarz, E.J., Dimaculangan, D.D., and Lazar, M.A. 1994. Peroxisome proliferator-activated receptor (PPAR) $\gamma$ : Adipose-predominant expression and induction early in adipocyte differentiation. Endocrinology 135: 798-800.

Christy, R.J., Yang, V.W., Ntambi, J.M., Geiman, D.E., Landschulz, W.H., Friedman, A.D., Nakabeppu, Y., Kelly, T.J., and Lane, M.D. 1989. Differentiation-induced gene expression in 3T3-L1 preadipocytes: CCAAT/enhancer binding protein interacts with and activates the promoters of two adipocyte-specific genes. Genes \& Dev. 3: 1323-1335.

Chui, P.C., Guan, H.P., Lehrke, M., and Lazar, M.A. 2005. PPAR $\gamma$ regulates adipocyte cholesterol metabolism via oxidized LDL receptor 1. J. Clin. Invest. 115: 2244-2256.

Dai, M., Wang, P., Boyd, A.D., Kostov, G., Athey, B., Jones, E.G., Bunney, W.E., Myers, R.M., Speed, T.P., Akil, H., et al. 2005. Evolving gene/transcript definitions significantly alter the interpretation of GeneChip data. Nucleic Acids Res. 33: e175. doi: 10.1093/nar/gnil79.

Darlington, G.J., Ross, S.E., and MacDougald, O.A. 1998. The role of C/EBP genes in adipocyte differentiation. J. Biol. Chem. 273: 30057-30060.

Dennis Jr., G., Sherman, B.T., Hosack, D.A., Yang, J., Gao, W., Lane, H.C., and Lempicki, R.A. 2003. DAVID: Database for annotation, visualization, and integrated discovery. Genome Biol. 4: 3. doi: 10.1186/gb-2003-4-9-r60.

DiRenzo, J., Soderstrom, M., Kurokawa, R., Ogliastro, M.H., Ricote, M., Ingrey, S., Horlein, A., Rosenfeld, M.G., and Glass, C.K. 1997. Peroxisome proliferator-activated receptors and retinoic acid receptors differentially control the interactions of retinoid $\mathrm{X}$ receptor heterodimers with ligands, coactivators, and corepressors. Mol. Cell. Biol. 17: 21662176.

Elberg, G., Gimble, J.M., and Tsai, S.Y. 2000. Modulation of the murine peroxisome proliferator-activated receptor $\gamma 2$ promoter activity by CCAAT/enhancer-binding proteins. $I$. Biol. Chem. 275: 27815-27822.

Freytag, S.O., Paielli, D.L., and Gilbert, J.D. 1994. Ectopic expression of the CCAAT/enhancer-binding protein $\alpha$ promotes the adipogenic program in a variety of mouse fibroblastic cells. Genes \& Dev. 8: 1654-1663.

Gearing, K.L., Gottlicher, M., Teboul, M., Widmark, E., and Gustafsson, J.A. 1993. Interaction of the peroxisome-proliferator-activated receptor and retinoid X receptor. Proc. Natl. Acad. Sci. 90: 1440-1444.

Gray, S.L., Dalla Nora, E., and Vidal-Puig, A.J. 2005. Mouse models of PPAR- $\gamma$ deficiency: Dissecting PPAR- $\gamma$ 's role in metabolic homoeostasis. Biochem. Soc. Trans. 33: 10531058.

Guan, H.P., Ishizuka, T., Chui, P.C., Lehrke, M., and Lazar, M.A. 2005. Corepressors selectively control the transcrip- 
tional activity of PPAR $\gamma$ in adipocytes. Genes \& Dev. 19: 453-461.

Hamm, J.K., Park, B.H., and Farmer, S.R. 2001. A role for $\mathrm{C} / \mathrm{EBP} \beta$ in regulating peroxisome proliferator-activated receptor $\gamma$ activity during adipogenesis in 3T3-L1 preadipocytes. J. Biol. Chem. 276: 18464-18471.

IJpenberg, A., Jeannin, E., Wahli, W., and Desvergne, B. 1997. Polarity and specific sequence requirements of peroxisome proliferator-activated receptor $(\mathrm{PPAR}) /$ retinoid $\mathrm{X}$ receptor heterodimer binding to DNA. A functional analysis of the malic enzyme gene PPAR response element. J. Biol. Chem. 272: $20108-20117$.

IJpenberg, A., Tan, N.S., Gelman, L., Kersten, S., Seydoux, J., Xu, J., Metzger, D., Canaple, L., Chambon, P., Wahli, W., et al. 2004. In vivo activation of PPAR target genes by RXR homodimers. EMBO J. 23: 2083-2091.

Irizarry, R.A., Hobbs, B., Collin, F., Beazer-Barclay, Y.D., Antonellis, K.J., Scherf, U., and Speed, T.P. 2003. Exploration, normalization, and summaries of high density oligonucleotide array probe level data. Biostatistics 4: 249-264.

Ji, X., Li, W., Song, J., Wei, L., and Liu, X.S. 2006. CEAS: Cisregulatory element annotation system. Nucleic Acids Res. 34 (Web Server issue): W551-W554. doi: 10.1093/nar/gkl322.

Johnson, W.E., Li, W., Meyer, C.A., Gottardo, R., Carroll, J.S., Brown, M., and Liu, X.S. 2006. Model-based analysis of tiling-arrays for ChIP-chip. Proc. Natl. Acad. Sci. 103: 1245712462.

Joseph, S.B., Laffitte, B.A., Patel, P.H., Watson, M.A., Matsukuma, K.E., Walczak, R., Collins, J.L., Osborne, T.F., and Tontonoz, P. 2002. Direct and indirect mechanisms for regulation of fatty acid synthase gene expression by liver $\mathrm{X}$ receptors. J. Biol. Chem. 277: 11019-11025.

Karolchik, D., Hinrichs, A.S., Furey, T.S., Roskin, K.M., Sugnet, C.W., Haussler, D., and Kent, W.J. 2004. The UCSC table browser data retrieval tool. Nucleic Acids Res. 32: D493D496.

Kent, W.J., Sugnet, C.W., Furey, T.S., Roskin, K.M., Pringle, T.H., Zahler, A.M., and Haussler, D. 2002. The human genome browser at UCSC. Genome Res. 12: 996-1006.

Kim, S., Yamazaki, M., Zella, L.A., Meyer, M.B., Fretz, J.A., Shevde, N.K., and Pike, J.W. 2007. Multiple enhancer regions located at significant distances upstream of the transcriptional start site mediate RANKL gene expression in response to 1,25-dihydroxyvitamin D3. I. Steroid Biochem. Mol. Biol. 103: 430-434.

Lee, T.I., Johnstone, S.E., and Young, R.A. 2006. Chromatin immunoprecipitation and microarray-based analysis of protein location. Nat. Protocols 1: 729-748.

Lehrke, M. and Lazar, M.A. 2005. The many faces of PPAR $\gamma$. Cell 123: 993-999.

Li, A.C. and Glass, C.K. 2004. PPAR- and LXR-dependent pathways controlling lipid metabolism and the development of atherosclerosis. J. Lipid Res. 45: 2161-2173.

Li, W., Carroll, J.S., Brown, M., and Liu, S. 2008. xMAN: Extreme mapping of oligonucleotides. BMC Genomics 9 (Suppl. 1): S20. doi: 10.1186/1471-2164-9-S1-S20.

Lupien, M., Eeckhoute, J., Meyer, C.A., Wang, Q., Zhang, Y., Li, W., Carroll, J.S., Liu, X.S., and Brown, M. 2008. FoxA1 translates epigenetic signatures into enhancer-driven lineage-specific transcription. Cell 132: 958-970.

MacDougald, O.A., Cornelius, P., Liu, R., and Lane, M.D. 1995. Insulin regulates transcription of the CCAAT/enhancer binding protein $(\mathrm{C} / \mathrm{EBP}) \alpha, \beta$, and $\delta$ genes in fully-differentiated 3T3-L1 adipocytes. J. Biol. Chem. 270: 647-654.

Matsukuma, K.E., Wang, L., Bennett, M.K., and Osborne, T.F. 2007. A key role for orphan nuclear receptor liver receptor homologue-1 in activation of fatty acid synthase promoter by liver X receptor. J. Biol. Chem. 282: 20164-20171.

Matys, V., Fricke, E., Geffers, R., Gossling, E., Haubrock, M., Hehl, R., Hornischer, K., Karas, D., Kel, A.E., Kel-Margoulis, O.V., et al. 2003. TRANSFAC: Transcriptional regulation, from patterns to profiles. Nucleic Acids Res. 31: 374-378.

Nakachi, Y., Yagi, K., Nikaido, I., Bono, H., Tonouchi, M., Schonbach, C., and Okazaki, Y. 2008. Identification of novel PPAR $\gamma$ target genes by integrated analysis of ChIP-on-chip and microarray expression data during adipocyte differentiation. Biochem. Biophys. Res. Commun. 372: 362-366.

Park, S.K., Oh, S.Y., Lee, M.Y., Yoon, S., Kim, K.S., and Kim, J.W. 2004. CCAAT/enhancer binding protein and nuclear factor-Y regulate adiponectin gene expression in adipose tissue. Diabetes 53: 2757-2766.

Perera, R.J., Marcusson, E.G., Koo, S., Kang, X., Kim, Y., White, N., and Dean, N.M. 2006. Identification of novel PPARy target genes in primary human adipocytes. Gene 369: 90-99.

Rangwala, S.M. and Lazar, M.A. 2004. Peroxisome proliferatoractivated receptor $\gamma$ in diabetes and metabolism. Trends Pharmacol. Sci. 25: 331-336.

Robinson, C.E., Wu, X., Morris, D.C., and Gimble, J.M. 1998. DNA bending is induced by binding of the peroxisome proliferator-activated receptor $\gamma 2$ heterodimer to its response element in the murine lipoprotein lipase promoter. Biochem. Biophys. Res. Commun. 244: 671-677.

Roh, T.Y., Wei, G., Farrell, C.M., and Zhao, K. 2007. Genomewide prediction of conserved and nonconserved enhancers by histone acetylation patterns. Genome Res. 17: 74-81.

Rosen, E.D., Hsu, C.H., Wang, X., Sakai, S., Freeman, M.W., Gonzalez, F.J., and Spiegelman, B.M. 2002. C/EBP $\alpha$ induces adipogenesis through PPAR $\gamma$ : A unified pathway. Genes \& Dev. 16: 22-26.

Sandelin, A., Alkema, W., Engstrom, P., Wasserman, W.W., and Lenhard, B. 2004. JASPAR: An open-access database for eukaryotic transcription factor binding profiles. Nucleic Acids Res. 32: D91-D94.

Schoonjans, K., Staels, B., and Auwerx, J. 1996. Role of the peroxisome proliferator-activated receptor (PPAR) in mediating the effects of fibrates and fatty acids on gene expression. $J$. Lipid Res. 37: 907-925.

Sears, D.D., Hsiao, A., Ofrecio, J.M., Chapman, J., He, W., and Olefsky, J.M. 2007. Selective modulation of promoter recruitment and transcriptional activity of PPAR $\gamma$. Biochem. Biophys. Res. Commun. 364: 515-521.

Siepel, A., Bejerano, G., Pedersen, J.S., Hinrichs, A.S., Hou, M., Rosenbloom, K., Clawson, H., Spieth, J., Hillier, L.W., Richards, S., et al. 2005. Evolutionarily conserved elements in vertebrate, insect, worm, and yeast genomes. Genome Res. 15: 1034-1050.

Song, J.S., Johnson, W.E., Zhu, X., Zhang, X., Li, W., Manrai, A.K., Liu, J.S., Chen, R., and Liu, X.S. 2007. Model-based analysis of two-color arrays (MA2C). Genome Biol. 8: R178. doi: 10.1186/gb-2007-8-8-r178.

Steger, D.J., Lefterova, M.I., Ying, L., Stonestrom, A.J., Schupp, M., Zhuo, D., Vakoc, A.L., Kim, J.E., Chen, J., Lazar, M.A., et al. 2008. DOT1L/KMT4 recruitment and H3K79 methylation are ubiquitously coupled with gene transcription in mammalian cells. Mol. Cell. Biol. 28: 2825-2839.

Teboul, L., Febbraio, M., Gaillard, D., Amri, E.Z., Silverstein, R., and Grimaldi, P.A. 2001. Structural and functional characterization of the mouse fatty acid translocase promoter: Activation during adipose differentiation. Biochem. I. 360: 305-312.

Temple, K.A., Cohen, R.N., Wondisford, S.R., Yu, C., Deplewski, D., and Wondisford, F.E. 2005. An intact DNA- 
Lefterova et al.

binding domain is not required for peroxisome proliferatoractivated receptor $\gamma(\operatorname{PPAR} \gamma)$ binding and activation on some PPAR response elements. J. Biol. Chem. 280: 3529-3540.

Tontonoz, P., Graves, R.A., Budavari, A.I., Erdjument-Bromage, H., Lui, M., Hu, E., Tempst, P., and Spiegelman, B.M. 1994a. Adipocyte-specific transcription factor ARF6 is a heterodimeric complex of two nuclear hormone receptors, PPAR $\gamma$ and RXR $\alpha$. Nucleic Acids Res. 22: 5628-5634.

Tontonoz, P., Hu, E., Graves, R.A., Budavari, A.I., and Spiegelman, B.M. 1994b. mPPAR $\gamma 2$ : Tissue-specific regulator of an adipocyte enhancer. Genes \& Dev. 8: 1224-1234.

Tontonoz, P., Hu, E., and Spiegelman, B.M. 1994c. Stimulation of adipogenesis in fibroblasts by PPAR $\gamma 2$, a lipid-activated transcription factor. Cell 79: 1147-1156.

Wang, Q., Carroll, J.S., and Brown, M. 2005. Spatial and temporal recruitment of androgen receptor and its coactivators involves chromosomal looping and polymerase tracking. Mol. Cell 19: 631-642.

West, A.G. and Fraser, P. 2005. Remote control of gene transcription. Hum. Mol. Genet. 14: R101-R111. doi: 10.1093/ hmg/ddil04.

Wu, Z., Xie, Y., Bucher, N.L., and Farmer, S.R. 1995. Conditional ectopic expression of C/EBP $\beta$ in NIH-3T3 cells induces PPAR $\gamma$ and stimulates adipogenesis. Genes \& Dev. 9: 2350-2363.

Wu, Z., Bucher, N.L., and Farmer, S.R. 1996. Induction of peroxisome proliferator-activated receptor $\gamma$ during the conversion of 3T3 fibroblasts into adipocytes is mediated by $\mathrm{C} / \mathrm{EBP} \beta, \mathrm{C} / \mathrm{EBP} \delta$, and glucocorticoids. Mol. Cell. Biol. 16: 4128-4136.

Wu, Z., Rosen, E.D., Brun, R., Hauser, S., Adelmant, G., Troy, A.E., McKeon, C., Darlington, G.J., and Spiegelman, B.M. 1999. Cross-regulation of C/EBP $\alpha$ and PPAR $\gamma$ controls the transcriptional pathway of adipogenesis and insulin sensitivity. Mol. Cell 3: 151-158.

Yajima, H., Kobayashi, Y., Kanaya, T., and Horino, Y. 2007. Identification of peroxisome-proliferator responsive element in the mouse HSL gene. Biochem. Biophys. Res. Commun. 352: $526-531$.

Yeh, W.C., Cao, Z., Classon, M., and McKnight, S.L. 1995. Cascade regulation of terminal adipocyte differentiation by three members of the C/EBP family of leucine zipper proteins. Genes \& Dev. 9: 168-181.

Zuo, Y., Qiang, L., and Farmer, S.R. 2006. Activation of CCAAT/enhancer-binding protein (C/EBP) $\alpha$ expression by $\mathrm{C} / \mathrm{EBP} \beta$ beta during adipogenesis requires a peroxisome proliferator-activated receptor- $\boldsymbol{\gamma}$-associated repression of HDAC1 at the C/ebp $\alpha$ gene promoter. J. Biol. Chem. 281: 7960-7967. 


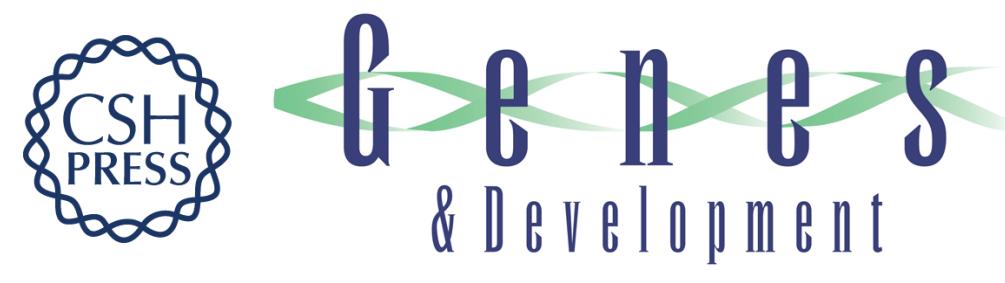

\section{PPAR $\gamma$ and C/EBP factors orchestrate adipocyte biology via adjacent binding on a genome-wide scale}

Martina I. Lefterova, Yong Zhang, David J. Steger, et al.

Genes Dev. 2008, 22:

Access the most recent version at doi:10.1101/gad.1709008

Supplemental http://genesdev.cshlp.org/content/suppl/2008/11/06/22.21.2941.DC1
Material

References This article cites 61 articles, 30 of which can be accessed free at: http://genesdev.cshlp.org/content/22/21/2941.full.html\#ref-list-1

License

Email Alerting Receive free email alerts when new articles cite this article - sign up in the box at the top Service right corner of the article or click here.

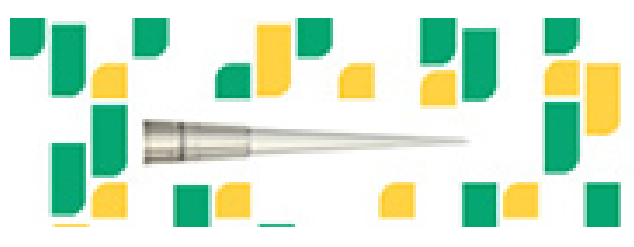

Focused on your science. 